\title{
Incidental Finding of Lamellar Calcification of the Falx Cerebri Leading to the Diagnosis of Gorlin-Goltz Syndrome
}

\author{
I. Saulite $^{\mathrm{a}}$ B. Voykov ${ }^{\mathrm{b}} \quad$ T. Mehra $^{\mathrm{d}} \quad$ W. Hoetzenecker $\quad$ E. Guenova ${ }^{\text {c, e }}$ \\ ${ }^{a}$ Department of Dermatology, Riga Stradinš University, Riga, Latvia; ${ }^{b}$ Centre for \\ Ophthalmology, and 'Department of Dermatology, University Hospital Tübingen, \\ Tübingen, Germany; ${ }^{\mathrm{d}}$ Medical Controlling and Statistics, and ${ }^{\mathrm{e}}$ Department of \\ Dermatology, University Hospital of Zurich, Zurich, Switzerland
}

\section{Key Words}

Gorlin-Goltz syndrome · Nevoid basal cell carcinoma syndrome $\cdot$ Calcification · Falx cerebri

\begin{abstract}
Here, we report the case of an incidental finding of lamellar calcification of the falx cerebri in a routine computed tomography scan of the head after an accidental trauma. This lamellar calcification led to the diagnosis of Gorlin-Goltz syndrome (GGS) in the patient and her daughter. Lamellar calcification of the falx cerebri is a pathognomonic feature of GGS. Our case report highlights the importance of a multidisciplinary diagnostic approach to GGS.
\end{abstract}

(c) 2013 S. Karger AG, Basel

\section{Introduction}

Gorlin-Goltz syndrome (GGS), or nevoid basal cell carcinoma syndrome, is an autosomal dominant genetic disease with an estimated prevalence of 1:57,000-1:256,000 and a high level of penetrance and variable expressiveness [1-3]. Calcification of the falx cerebri is one of the major diagnostic criteria of GGS that can be detected in 79\% of patients with GGS [4].

Wolfram Hoetzenecker, MD, PhD

Department of Dermatology, University Hospital of Zurich

Gloriastrasse 31

$\mathrm{CH}-8091$ Zurich (Switzerland)

E-Mail wolfram.hoetzenecker@usz.ch 
Saulite et al.: Incidental Finding of Lamellar Calcification of the Falx Cerebri Leading to the Diagnosis of Gorlin-Goltz Syndrome

\section{Case Report}

A 53-year-old woman was referred to a radiologist for performance of a routine computed tomography scan of the head to exclude intracranial hemorrhage after accidental head trauma. The computed tomography imaging detected lamellar calcification of the falx cerebri, which is a pathognomonic feature of GGS (fig. 1) [5]. Meeting the criteria for GGS and considering the pathognomonic feature of the lamellar calcification (major criterion for GGS), the patient was referred to the Department of Dermatology.

An examination of the patient's skin showed multiple small lesions clinically resembling basal cell carcinomas (BCCs) on the back, for which shave excisions were carried out. One suspected nodular BCC on the nose was removed by Mohs micrographic surgery. Pathologic examination of the lesions revealed 9 superficial BCCs on the back and 1 nodular BCC on the nose. The patient reported that the first BCC had occurred at the age of 27 years, and subsequently 4 other superficial BCCs had been removed by shave excision until the diagnosis of GGS was established. Furthermore, the patient presented with multiple palmar pits and marked syndactyly of the toes. Therefore, in our case, 2 major criteria [(I) lamellar calcification of falx cerebri, and (II) more than 2 BCCs] and 1 minor criterion (marked syndactyly of digits) were detected [6]. Additionally, the diagnosis of GGS was confirmed by positive testing for mutations in the tumor suppressor gene PTCH. Taking into account that GGS is an autosomal dominant genetic disease with nearly full penetrance and variable expressivity [7], the daughters of our patient were screened for PTCH gene mutations as well. Although they both had no BCCs upon clinical inspection and none recorded in their medical history, one of the daughters tested positive for a PTCH gene mutation.

\section{Discussion}

As a consequence, our patient and her daughter are now being screened for BCCs on a regular basis as well as having been made aware of the necessity for adequate primary prophylaxis of skin cancer, such as the avoidance of excessive exposure to ultraviolet radiation [8]. As GGS is a genetic syndrome affecting different organs, early recognition of the specific criteria for GGS is crucial $[8,9]$. In our case, the incidental finding of lamellar calcification of the falx cerebri of the head finally led to the diagnosis of GGS. Our case report highlights the importance of a multidisciplinary diagnostic approach to GSS. Physicians should always approach GGS patients systematically, thus remarkably improving clinical outcomes [8].

\section{Disclosure Statement}

The authors have no conflict of interests. This work was partly funded by a research grant from the German Research Foundation (GU1271/2-1) to E.G.

\section{References}

1 Lo Muzio L: Nevoid basal cell carcinoma syndrome (Gorlin syndrome). Orphanet J Rare Dis 2008;3:32.

-2 Kiran NK, Tilak Raj TN, Mukunda KS, Rajashekar Reddy V: Nevoid basal cell carcinoma syndrome (GorlinGoltz syndrome). Contemp Clin Dent 2012;3:514-518. 
Saulite et al.: Incidental Finding of Lamellar Calcification of the Falx Cerebri Leading to the Diagnosis of Gorlin-Goltz Syndrome

-3 Jawa DS, Sircar K, Somani R, Grover N, Jaidka S, Singh S: Gorlin-Goltz syndrome. J Oral Maxillofac Pathol 2009;13:89-92.

-4 Kimonis VE, Mehta SG, Digiovanna JJ, Bale SJ, Pastakia B: Radiological features in 82 patients with nevoid basal cell carcinoma (NBCC or Gorlin) syndrome. Genet Med 2004;6:495-502.

5 Lambrecht JT, Stübinger S, Siewert B, Härle F: Calcification of the falx cerebri. A pathognomonic symptom of Gorlin-Goltz syndrome (in German). HNO 2005;53:701-704.

6 Kimonis VE, Goldstein AM, Pastakia B, Yang ML, Kase R, DiGiovanna JJ, Bale AE, Bale SJ: Clinical manifestations in 105 persons with nevoid basal cell carcinoma syndrome. Am J Med Genet 1997;69:299_ 308.

7 Boutet N, Bignon Y-J, Drouin-Garraud V, Sarda P, Longy M, Lacombe D, Gorry P: Spectrum of PTCH1 mutations in French patients with Gorlin syndrome. J Invest Dermatol 2003;121:478-481.

-8 Veenstra-Knol HE, Scheewe JH, van der Vlist GJ, van Doorn ME, Ausems MG: Early recognition of basal cell nevus syndrome. Eur J Pediatr 2005;164:126-130.

-9 Jones EA, Sajid MI, Shenton A, Evans DG: Basal cell carcinomas in gorlin syndrome: a review of 202 patients. J Skin Cancer 2011;2011:217378.

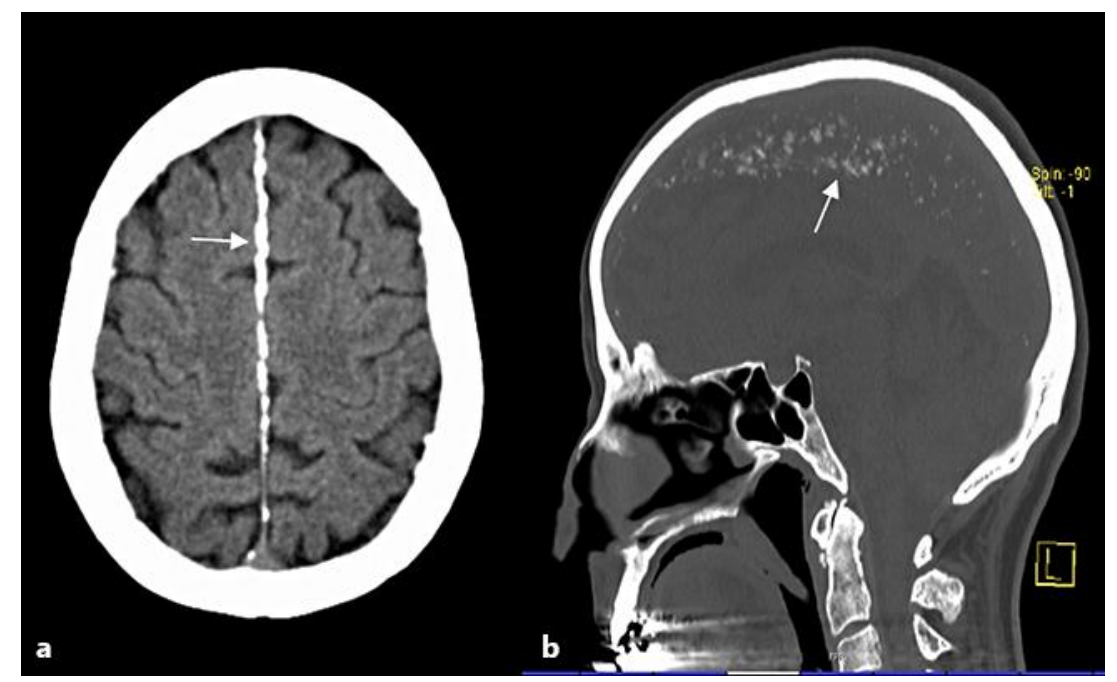

Fig. 1. Calcification of the falx cerebri. Brain computed tomography scan showing lamellar calcifications of the falx cerebri (white arrow). a Axial view. b Sagittal view. 